\title{
Interest Margins and Banks' Asset-Liability Composition
}

\section{Idrees Khawaja*}

\begin{abstract}
This article examines the determinants of banks' interest margins. The results suggest that short-term government bonds (floating debt) and the large share of interest-insensitive deposits held by banks are the key determinants of the interest margin. This is in contrast to the popular perception that the market power of the oligopolistic industry contributes to banks' high interest margins. While a behavioral change-a greater inclination to save and an increase in output-might reduce the share of interest-insensitive deposits, the reduction in government debt depends on the state of certain macro-variables and macroeconomic management. Given these determinants and the possible ways of containing margins, the containment process is a tall order. The study also implicitly confirms that government borrowing is crowding out private investment.
\end{abstract}

Keywords: Interest Margin, Banks, Pakistan.

JEL Classification: G21, G12.

\section{Introduction}

The rather high interest margin of banks has been a recent cause for concern for the authorities in Pakistan. This prompted the central bank (State Bank of Pakistan) to fix a mandatory floor rate on savings deposits (the features of which are more or less similar to a remunerative checking account) in January 2008. However, the interest margin did not decline despite the mandatory floor; rather, based on the coupon rate, the margin on fresh loans and deposits increased from 5.14 percent in December 2007 to 7.15 percent in March 2011. It is worth mentioning here that we consider the savings deposit to be largely insensitive to the rate of return offered. Therefore, even though the increase in returns on savings deposits may increase the income of the existing depositors, the floor rate on savings deposits may not serve to encourage savings and investment.

\footnotetext{
${ }^{*}$ Associate Professor, Pakistan Institute of Development Economics (P.I.D.E), Islamabad.
} 
In recent years, the government's domestic debt has increased enormously. The government's frenzy to borrow on the back of high interest rates has provided banks with an attractive investment avenueone that is more attractive than lending. The higher return on government paper, if not passed on to the deposit and lending rate, serves to raise banks' interest margin. Although the implications of domestic debt have been studied extensively, the variable has not been examined as a determinant of the interest margin.

The forgoing discussion looks afresh at the determinants of the interest margin in order to inform policymaking. ${ }^{1} \mathrm{~A}$ high interest margin has several adverse implications for the economy: it discourages savings and investments (Khawaja \& Din, 2007); misallocates resources; and maldistributes income. What is of greater concern to the authorities is that the high interest margin constrains the effectiveness of the interest rate channel of monetary policy, as the changes in the policy rate are not fully transmitted to the lending and deposit rates. ${ }^{2}$ Over time, the banking industry in Pakistan has changed from public to private, with a large chunk of banking assets being held by the private sector by 2002. The determinants of the interest margin could be different under the private sector and public sector: while only the profit motive would motivate the private sector, the public sector might care about agents' welfare. Moreover, while public sector banks enjoy preferential access to low-cost government funds, they might well have to become involved in preferential and low-yield lending to the government and state-owned enterprises. The relatively smaller risk attached to deposits held by public sector banks might also allow them to tap into a larger market share. This is the first study to examine the determinants of the interest margin, with a data span (2002-09) selected such that around 80 percent of banking operations are in the private sector.

The study is organized as follows. Section 2 presents a brief review of the literature. The methodology, which emphasizes the rationale for the variables included in the model, is discussed in Section 3. Section 4 explains data construction, and Section 5 presents the results followed by interpretation and analysis. Some further discussion of the results follows in Section 6, and Section 7 concludes the study.

\footnotetext{
1 This study extends Khawaja and Din (2007) on the determinants of interest spread. Here, we include short-term government debt in the model, which has become salient, given the government's huge domestic borrowings. We also examine separately the determinants of individual components (i.e., assets and liabilities) of the margin.

2 For a discussion and empirical evidence on the impact of monetary policy at the level of real economic activity, see Bernanke and Blinder (1992), Friedman and Schwartz (1963), and Romer and Romer (1989).
} 


\section{Literature Review}

The determinants of the interest margin have been explored by a vast body of literature. The concentration of the industry is the most examined variable. The industrial organization literature predicts that an oligopolistic market structure may contribute to a higher interest margin (Samuel \& Valderrama, 2006). Broadly, the salient determinants of the margin include: (i) the industry's market structure, (ii) bank-specific variables, (iii) macroeconomic variables, and (iv) financial regulations. Bain's (1951) structure-conduct-performance (SCP) hypothesis holds that firms in a concentrated market are able to collude to pay relatively less on their liabilities and charge more on their assets, thereby increasing the margin. Ho and Saunders (1981) view the bank as "a dealer" that demands depositors and suppliers of loans, and argue that the bank's interest margin depends on four factors: the degree of the bank management's risk aversion, the market structure of the industry, the average size of bank transactions, and the variance of interest rates. In addition, the authors reckon that a number of imperfections and regulatory restrictions have an impact on spread, and consider the probability that loan defaults and the opportunity cost of holding mandatory reserves are additional variables that influence the spread. Neumark and Sharpe (1992) implicitly confirm the SCP hypothesis for the US. They find that banks in concentrated markets are slower to raise deposit rates in response to rising market interest rates, but faster to reduce these in response to declining market rates, thereby maintaining higher spreads.

Corvoisier and Gropp (2001) examine the hypothesis for Euroarea countries, and confirm that the SCP hypothesis holds for loan and demand deposit rates, but not for savings and time deposit rates. Hannan and Liang (1993) and Barajas, Steiner, and Salazar (1999), using data for the US and Colombia, also suggest that industry concentration might lead to a higher spread. Prager and Hannan (1998) examine the price effects of US bank mergers that led to a substantial increase in local market concentration, and find that, during 1991-94, the deposit rates offered in local markets where mergers took place declined proportionately more than in markets without mergers. Sapienza (2002) examines the effect of banking consolidation on banks' credit policies in Italy, and reports that, in the case of in-market mergers, the interest rates charged by consolidated banks decrease if the merger involves the acquisition of banks with a small market share. However, as the local market share of the acquired bank increases, the decline is offset by market power. Edwards (1965) examines the impact of concentration and competition in 
the US banking industry, and finds that mergers have a greater negative impact on performance in less concentrated markets. Regulators should, therefore, be wary of mergers in less concentrated markets as much as they are in more concentrated markets.

\section{Methodology and Data}

We draw on the dealership model of the interest margin used by Martinez-Peria and Mody (2004) to specify a model to examine the determinants of the interest margin in Pakistan. The model predicts that the market structure of the banking sector, its operating cost, the cost of regulating the sector, and various macroeconomic variables may affect the interest margin. Here, we also include the short-term government debt held by banks as a determinant of the interest margin, which previous studies have not done.

The motivation is that banks find it beneficial to invest in government paper on several counts: investment in government paper is less risky, it does not entail a large administrative and analytical cost to make an investment decision, and above all, if the monetary stance is tight, the return on government paper might be such that the investment becomes an attractive opportunity on its own. The cost of investing in government paper is smaller and the return relatively larger; such investment is likely to raise the margin if banks do not pass on the higher returns to their customers, i.e., borrowers and depositors. The inclusion of government bonds in the model is all the more important given the anecdotal evidence that government bonds crowd out lending to the private sector.

Taking our lead from Khawaja and Din (2007), we also include in our model the share of interest-insensitive deposits held by banks. The rationale is that banks need not offer a higher return on such deposits, the flows of which are insensitive to the interest rate offered. Thus, a larger share of interest-insensitive deposits could lower the overall cost of funds for banks, and thereby raise the interest margin. Around 50 percent of the business volume - both deposits and lending - is held by five or six major banks. Given that a significant portion of these deposits, which we term interest-insensitive deposits, comes to the bank on its own (i.e., without any effort on the bank's part), the cost to the bank of deposit mobilization is likely to be rather low. For example, government departments bank mostly with the state-owned National Bank of Pakistan, while the armed forces bank only with Askari, which is owned by the Army Welfare Trust that was set up to promote the welfare of retired army employees. 
Similarly, many people deposit money in banks for the sole purpose of safety, and are not concerned about the rate of return. Deposit products typically offered by banks in Pakistan include current deposits, savings deposits, and fixed deposits. Deposits held in current accounts are zero-rated, i.e., they do not earn any interest and are therefore insensitive to changes in the interest rate. We treat the deposits held in savings accounts as interest-insensitive because they are held typically by small depositors and salaried persons who maintain these accounts to fulfill everyday banking needs rather than to earn interest. The category of "other deposit accounts" constitutes a negligible percentage of total deposits, and its inclusion on either side is not likely to influence results. These deposits are also interest-insensitive. Theoretically, changes in the policy rateproxied here by the six-month treasury-bill rate-should be passed on, in a competitive environment, one for one, to deposit rates. However, interestinsensitive deposits enable a bank to keep to itself all or part of a favorable change in interest rates and pass on to agents the entire burden or even more if the change in policy rate is adverse for the bank. Thus, the greater the interest-insensitivity of deposits, the higher is the interest margin. Given that current deposits (checking accounts) and saving deposits, which we consider insensitive, constitute a sizable portion (66 percent) of total industry deposits in 2009, the inclusion of interest-insensitive deposits in the model is all the more important. Our model is written as:

$$
Y i t=\alpha 0+\beta X i t+e i t
$$

Here, yit is the interest margin, defined as the difference between the interest earned on average assets and the interest paid on average liabilities; $(\alpha, \beta)$ are vectors of parameters, eit is the stochastic error term, and Xit is a vector of explanatory variables which includes the following.

Industry variables

(i) Concentration.

(ii) Interest-insensitivity of deposits.

Firm (bank) variables

(i) Market share.

(ii) Liquidity.

(iii) Administrative cost.

(iv) Nonperforming loans. 
(v) Equity.

Macro-variables

(i) Short-term debt (the government's floating debt).

(ii) Real output.

(iii) The real interest rate.

The literature on industrial organization offers two competing hypotheses regarding the market structure of the industry. The SCP hypothesis holds that market concentration leads to collusion among firms. With the cost of collusion being smaller in a concentrated market, firms are able to collude and thereby reap rents. Given market power, a bank would earn more on assets than is possible in a competitive market, and pay relatively less on liabilities, thereby raising the interest margin. If the SCP hypothesis holds, then the concentration variable should carry a positive sign.

The efficient-structure hypothesis asserts that the efficient operation of leading firms in the industry drive out the less efficient ones, the market becomes concentrated, and firms earn Ricardian rents. To the extent that efficiency is represented by the lower marginal cost of producing output of a given quality, banks in concentrated markets should find it advantageous to charge lower interest on loans and offer higher interest on deposits, thereby decreasing the margin. Thus, if the efficient-structure hypothesis holds, then the concentration variable should carry a negative sign. Given the conflicting predictions of the two hypotheses, we use an ambiguous sign for the concentration variable. The two hypotheses have been tested extensively for the banking industry (Berger \& Hannan, 1989).

Besides industry concentration, the two variables of primary interest are the volume of short-term government bonds (floating debt) and interest-insensitive deposits. We hypothesize that both carry a positive sign. Floating debt is expected to bear a positive sign because, as the debt increases, interest rates are likely to go up, thereby increasing the yield on government paper and advances for banks. Ceteris paribus, this raises the margin. Typically, a bank would pay less on interest-insensitive deposits. Therefore, the larger the share of interest-insensitive deposits in a bank's total deposits, the smaller the average cost of funds. This would raise the margin and, therefore, justify the positive sign on interest- 
insensitive deposits. The remaining variables in Equation (1) are control variables. The coefficient on liquidity is hypothesized to be negative because liquidity has an opportunity cost, i.e., the cost of not investing in high-yield assets such as "advances." Therefore, the increase in liquidity should make a dent in the interest margin.

The equity held by a bank also carries an opportunity cost. If the bank manages to pass on this cost to its depositors and borrowers, then the spread would vary positively with equity. Failure to do so would decrease the bank's interest margin. Given the conflicting expectations, we posit an ambiguous sign on equity. If the bank has to incur a greater intermediation cost when mobilizing deposits or lending funds, it would attempt to recover the cost by paying less on deposits and charging more on loans. Therefore, the interest margin should vary positively with the intermediation cost.

Nonperforming loans-loans that a bank fails to recover-inflict a cost on the bank, and should cause the margin to shrink. The market share of a bank in the industry reflects the former's market power and influences the margin positively. However, the scale economies that accompany a larger market size may allow the bank to charge its borrowers less and offer its depositors more. If this happens, the margin would vary negatively with market share. This conflict leads us to posit an ambiguous sign on the market share of an individual bank.

The macroeconomic environment has the potential to influence a bank's interest margin. Thus, we control for the impact of real output and the real interest rate on the interest margin. Real output growth captures the impact of a business cycle on the interest margin. In this context, Bernanke and Gertler (1989) argue that a slowdown in economic activity adversely affects borrowers' net worth and hence reduces the interest margin (positive effect). The coefficient on the real interest rate would depend on the extent to which changes in the rate are passed on by the bank to its customers. A one-for-one pass-through would result in a positive sign on the real interest rate coefficient, while a smaller passthrough would result in a different sign.

\section{Data}

We measure the interest margin as the difference between the return on average assets and the cost of average funds for individual banks. The return on average assets and cost of average funds are 
respectively computed as the total interest income to average assets and total interest paid to average funds. Assets comprise advances and liquid assets while borrowed funds include deposits and borrowings. The averages are worked out by taking the average of the balances held at the beginning and end of the year. The Hirschmann-Herfindhal index is used to work out the degree of concentration in the banking industry. Deposit accounts other than deposits of fixed maturity are considered interestinsensitive. For reasons explained earlier, deposits held in current (checking) accounts, savings accounts, and other accounts comprise interest-insensitive deposits.

Each bank's market share constitutes its total deposits as a percentage of the industry's total deposits; nonperforming loans comprise the ratio of provision for bad and doubtful debts to advances; administrative costs represent the cost of administration as a proportion of the bank's total assets; and liquidity is the ratio of liquid assets to total assets. The data on the industry and firm variables has been obtained from the State Bank of Pakistan's annual Banking Statistics of Pakistan. The data on macroeconomic variables, i.e., real output growth and the real interest rate, is taken from the State Bank's annual reports.

We use panel data for 22 banks (listed in Annexure 1) for the period 2002-09 in this study. To obtain a balanced panel, we have included only those banks that have existed continuously from 2002 to 2009. We start with 2002 because the kind of ownership-public or private-could have a bearing on the interest margin. Banks in Pakistan were taken over by the government in 1973 and all major banks remained in the public sector from 1973 to 1991. The privatization of banks was initiated in 1990, with two of the five largest banks being privatized in 1990 and 1991, and another two being privatized in 2001 and 2002. One of these banks, the National Bank of Pakistan, still belongs to the public sector. To avoid the problem of regime changes during the period under study, we take 2002 as the starting point of our investigation.

The use of panel data allows us to identify and measure the effects that one could not have observed in a pure cross-section or pure timeseries dataset. Models based on panel data can be estimated using either the random effects model or the fixed effects model. The random effects model assumes the exogeneity of all regressors with random individual effects, while the fixed effects model allows for the endogeneity of all regressors with individual effects (Baltagi, 2001). Here, we use the fixed effects model. 


\section{Empirical Findings}

We estimate Equation 1 using the fixed effect model. The results are reported in Table 1 below.

Table 1

Coefficient estimates of Equation (1)

Dependent variable: Interest spread

Sample size: 154 observations covering 22 banks and 7 years

Estimation method: Fixed effect model

White heteroscedasticity-consistent standard errors and covariance

\begin{tabular}{lc}
\hline & Coefficients \\
\hline Concentration & 1.32 \\
Inelasticity & $1.36^{* *}$ \\
Floating debt & $2.24^{* * *}$ \\
Nonperforming loans & 0.009 \\
Market share & -0.12 \\
Liquidity & -0.34 \\
Equity & 0.07 \\
Administrative cost & $0.33^{* * *}$ \\
GDP growth & $0.14^{* *}$ \\
Real interest rate & $-0.51^{* * *}$ \\
& \\
R2 & 0.95 \\
\hline
\end{tabular}

Note: ${ }^{* * *},{ }^{* *},{ }^{*}$ reflect significance at the $1 \%, 5 \%$, and $10 \%$ level, respectively.

The three variables of interest to us are (i) the volume of shortterm government debt held by banks, (ii) interest-sensitive deposits, and (iii) market concentration. The results suggest that the strongest and largest influence on the interest margin comes from the short-term debt variable. In recent years, the government has been borrowing heavily, using treasury bills. Table 2 shows that, since 2004, the government's short-term debt as a percentage of gross domestic product (GDP) has shown secular growth. The growth in government debt has been accompanied by growth in the yield on treasury bills. The government's short-term debt is raised typically through treasury bills that are purchased primarily by banks. Thus, the increase in government debt implies that a greater volume is available to banks for investment in 
government papers. If banks have to choose between lending to the private sector and investing in government paper, they are likely to choose the latter (treasury bills) on which the return has, over the years, remained higher than the lending rate (Table 2). Given that investment in government paper is risk-free, it becomes preferable compared to the lending option. Moreover, the cost of investing in government paper is substantially smaller than the cost of lending, which further encourages banks to invest in government paper. Therefore, if banks invested more in government paper, the higher yield on government debt would raise the return on investment and, hence, the interest margin, if changes in the yield are not passed on, one for one, to banks' customers. The higher net yield on government paper coupled with the low risk raises the return on investment for banks, causing the interest margin to increase.

The second important determinant of the interest margin is the interest-insensitive deposits variable. Our results show that these deposits exercise a positive impact on the interest margin, i.e., the greater the share of interest-insensitive deposits held by a bank, the larger the interest margin is likely to be. It is evident that the availability of interestinsensitive deposits to banks in large volumes leaves them with little incentive to offer a higher return on deposits or to make vigorous efforts to mobilize interest-bearing deposits. It is apparent from Table 2 that, although the share of interest-insensitive deposits in the industry's total deposits has declined over the years, the share remains rather high.

Table 2

\begin{tabular}{ccccccc}
\hline Year & $\begin{array}{c}\text { Inelastic } \\
\text { Current } \\
+ \\
\text { Savings }\end{array}$ & $\begin{array}{c}\text { Elastic } \\
\text { Deposits } \\
\text { of Fixed } \\
\text { Maturity }\end{array}$ & $\begin{array}{c}\text { Treasury } \\
\text { Bill Rate }\end{array}$ & $\begin{array}{c}\text { Floating } \\
\text { Debt/GDP }\end{array}$ & $\begin{array}{c}\text { Lending } \\
\text { Rate }\end{array}$ & $\begin{array}{c}\text { Interest } \\
\text { Margin }\end{array}$ \\
\hline 2002 & 77 & 23 & 4.3 & 13.5 & 9.95 & 6.7 \\
2003 & 85 & 15 & 1.6 & 10.7 & 5.68 & 4.3 \\
2004 & 83 & 17 & 3.7 & 10.3 & 5.92 & 4.1 \\
2005 & 75 & 25 & 8.8 & 12.5 & 9.53 & 5.3 \\
2006 & 71 & 29 & 9.0 & 13.2 & 11.16 & 5.6 \\
2007 & 69 & 31 & 9.4 & 13.4 & 10.95 & 5.1 \\
2008 & 65 & 35 & 14.3 & 16.5 & 14.33 & 5.4 \\
2009 & 66 & 34 & 12.1 & 15.8 & 13.71 & 6.3 \\
\hline
\end{tabular}

Source: State Bank of Pakistan, banking statistics and economic data retrieved from www.sbp.org.pk. 
Despite the decline in the share of interest-insensitive deposits, the interest margin has not declined. This suggests that other variables-in addition to the share of interest-insensitive deposits-influence the interest margin.

The concentration ratio does not exercise a statistically significant influence on the interest margin. The availability of interest-insensitive deposits in large volumes leaves banks with little incentive to collude or adopt competitive practices, and these deposits fall into their laps. Therefore, the concentration ratio that reflects competitive behavior or the lack thereof fails to exercise any worthwhile influence on the interest margin. However, the industry's oligopolistic market structure allows banks to retain the higher return for themselves. Thus, the concentration of the industry matters implicitly.

Banks' intermediation cost also affects the interest margin significantly, and the positive sign on the estimated coefficient implies that banks are able to pass on changes in the intermediation cost to their customers. Banks' liquidity and equity also fail to have a statistically significant impact on the interest margin. The influence of real output and the real interest rate on the interest margin is positive. This implies that, as income increases, the demand for and therefore the return on loans increases, causing the margin to rise. The real interest rate casts a significant negative influence on the interest margin, implying that banks do not pass on all changes in the real interest rate to their agents. The results reported above are robust given different alternative specifications. We check the robustness by dropping the statistically insignificant coefficients one at a time.

One of the disadvantages of examining the determinants of the margin at the aggregate level is that one has to include such variables in the model that affect only earning assets or liabilities that cost something. For example, the share of interest-insensitive deposits would only influence the cost of funds, but not the return on assets. To take care of this issue, we have examined the robustness of results by estimating the determinants of earning assets and paying liabilities separately by including such variables in the model that are likely to influence its individual components. The results, reported in Annexure 2, show that the share of interest-insensitive deposits is the primary determinant of the cost of funds, and the volume of government debt is one of the major determinants of the return on assets. These findings support the results reported for the interest margin in Table 1 above. 


\section{Further Discussion}

The question that begs an answer is, what can be done to raise the interest margin? The answer is, not much. However, to answer the question more clearly, one must first ask what the objective of containing the interest margin is. Is it depositors' welfare or an effort to encourage savings and investment? If the former, perhaps continuing with a floor rate on savings deposits would be the correct policy to pursue. However, although the floor rate on savings deposits has yielded greater returns to depositors, the policy has merely raised the return on those deposits that were meant to be in the banking system even if the rate was not enhanced.

Researchers and the authorities must grapple with the question as to how to decrease the interest margin to increase savings and investment, and enhance the effectiveness of the interest rate channel of monetary policy. With the source of a high interest margin being the interest-insensitivity of a significant percentage of depositors and the short-term debt of the government, finding a way to cause a dent in the interest margin in a manner that encourages savings and investment will prove difficult. Curbing the former source calls for a behavioral changea change in the behavior of depositors, making them more returnconscious. Economic growth might also contribute to increasing the share of interest-sensitive deposits, as there would be more money to save. Tackling the latter-a reduction in government debt-calls for containing the fiscal deficit, which boils down to improving the whole set of macroeconomic variables and macroeconomic management.

\section{Conclusion}

Banks' interest margin has remained on the higher side throughout the previous decade. Policy efforts initiated in January 2008 to contain the margin have yet to yield dividends. Moreover, this policy effort seems directed more at improving the welfare of depositors than encouraging savings and investment. The study finds that the (i) government's short-term debt-which is an attractive investment avenue for banks-and (ii) the share of interest-insensitive deposits are the two primary determinants of the high interest margin. Thus, the present structure of banks' assets and liabilities keeps the margin on the higher side. Given the determinants of and the ways in which this margin might be contained, the process is likely to prove a tall order. 


\section{References}

Bain, J. S. (1951). Relation of profit rate to industry concentration. Quarterly Journal of Economics, 65, 293-324.

Baltagi, B. H. (2001). Econometric analysis of panel data. New York, NY: John Wiley \& Sons.

Barajas, A., Steiner, R., \& Salazar, N. (1999). Interest rate spreads in banking in Colombia, 1974-96. International Monetary Fund Staff Papers, 46, 196-224.

Berger, A. N., \& Hannan, T. H. (1989). The price-concentration relationship in banking. Review of Economics and Statistics, 71, 291299.

Bernanke, B., \& Blinder, A. (1992). Credit, money, and aggregate demand. American Economic Review, 82, 901-921.

Bernanke, B., \& Gertler, M. (1989). Agency costs, net worth, and business fluctuations. American Economic Review, 79, 14-31.

Corvoisier, S., \& Gropp, R. (2001). Bank concentration and retail interest rates (Working Paper No. 72). Frankfurt, Germany: European Central Bank.

Edwards, F. R. (1965). Concentration and competition in commercial banking: A statistical study. Journal of Finance, 20(1), 101-102.

Friedman, M., \& Schwartz, A. (1963). A monetary history of the United States, 1867-1960. Princeton, NJ: Princeton University Press.

Hannan, T., \& Liang, J. N. (1993). Bank commercial lending and the influence of thrift competition (Finance and Economics Discussion Series 9339). Washington, DC: US Board of Governors of the Federal Reserve System.

Heggestad, A. A., \& Mingo, J. J. (1976). Price, non-prices, and concentration in commercial banking. Journal of Money, Credit, and Banking, 8(1), 107-117. 
Ho, T., \& Saunders, A. (1981). The determinants of bank interest margins: Theory and empirical evidence. Journal of Financial and Quantitative Analysis, 16, 581-600.

Martinez-Peria, M. S., \& Mody, A. (2004). How foreign participation and market concentration impact bank spreads: Evidence from Latin America. Journal of Money, Credit, and Banking, 36(3), 511-537.

Mishkin, F. S. (1995). Symposium on the monetary transmission mechanism. Journal of Economic Perspectives, 9(4), 3-10.

Neumark, D., \& Sharpe, S. A. (1992). Market structure and the nature of price rigidity: Evidence from the market for consumer deposits. Quarterly Journal of Economics, 107(2), 657-680.

Prager, R. A., \& Hannan, T. H. (1998). Do substantial horizontal mergers generate significant price effects? Evidence from the banking industry. Journal of Industrial Economics, 46, 433-452.

Romer, C., \& Romer, D. (1989). Does monetary policy matter? A new test in the spirit of Friedman and Schwartz. National Bureau of Economic Research Macroeconomic Annual, 4, 121-170.

Samuel, W., \& Valderrama, L. (2006). The monetary policy regime and banking spreads in Barbados (Working Paper No. 06/211). Washington, DC: International Monetary Fund.

Sapienza, P. (2002). The effects of banking mergers on loan contracts. Journal of Finance, 57, 329-367. 


\section{Banks Included in Sample}

1 National Bank of Pakistan

2 Habib Bank Limited

3 United Bank Limited

4 Muslim Commercial Bank

5 Allied Bank of Pakistan

6 Alfalah Bank Limited

$7 \quad$ Al-Habib Bank Limited

8 Askari Bank Limited

9 Faysal Bank Limited

10 First Women Bank

11 Bank of Punjab

12 Khyber Bank Limited

13 My Bank Limited

14 Habib Metropolitan Bank Limited

15 Soneri Bank Limited

16 Al-Baraka Limited

17 Oman Bank Limited

18 Tokyo Bank

19 Citibank

20 Deutsche Bank

21 Hong Kong-Shanghai Bank

22 Standard Chartered Bank 


\section{Table 3}

Dependent variable: Return on earning assets

Sample size: 154 observations covering 22 banks and 7 years

Estimation method: Fixed effect model

White heteroscedasticity-consistent standard errors and covariance

\begin{tabular}{lc}
\hline & Coefficients \\
\hline Concentration & 2.26 \\
Short-term government debt & $2.39^{*}$ \\
Nonperforming loans & $-0.03^{* *}$ \\
Market share & $0.26^{* * *}$ \\
Liquidity & $-0.53^{* * *}$ \\
Equity & 0.003 \\
Administrative cost & $0.23^{* * *}$ \\
GDP growth & 0.24 \\
Real interest rate & -0.07 \\
Constant & -7.89 \\
& \\
R2 & 0.98 \\
\hline
\end{tabular}

Note: ${ }^{* * *}, * *,{ }^{*}$ reflect significance at $1 \%, 5 \%$, and $10 \%$ level, respectively.

\section{Table 4}

Dependent variable: Cost of funds

Sample size: 154 observations covering 22 banks and 7 years

Estimation method: Fixed effect model

White heteroscedasticity-consistent standard errors and covariance

\begin{tabular}{lc}
\hline & Coefficients \\
\hline Concentration & $23.39^{* * *}$ \\
Interest Insensitive Deposits & $-18.41^{* * *}$ \\
Market Share & $0.19^{* * *}$ \\
Equity & -0.0002 \\
Administrative Cost & 0.006 \\
GDP Growth & $-0.0007^{* * *}$ \\
Real Interest rate & $0.002^{* * *}$ \\
Constant & $0.09^{* * *}$ \\
& \\
R2 & 0.98 \\
\hline
\end{tabular}

Note: ${ }^{* * *}, * * *$ reflect significance at $1 \%, 5 \%$, and $10 \%$ level, respectively. 